\title{
Utilization of Liquid Smoke for Odor Control at the Final Disposal Site Kalibaru, Banyuwangi
}

\author{
Rosyid Ridho', M. Sabiq Irwan H.2, Eko Malis ${ }^{3}$, Mislan ${ }^{4}$ \\ 1,2,3,4 Universitas PGRI Banyuwangi \\ Email: 1rosyidridho@gmail.com, 2sabiqirwan@unibabwi.ac.id, ${ }^{3}$ ekomalis@unibabwi.ac.id, \\ 4mislanmpd680@gmail.com \\ doi https://doi.org/10.36526/gandrung.v2i1.1224
}

\begin{abstract}
The implementation of community service with the theme of utilizing liquid smoke for odor control in garbage at the Kalibaru Final Disposal Site has been carried out. This service was carried out in three stages, namely counseling, visits to liquid smoke factories and application of liquid smoke to garbage. The results of these activities in general, the community really understands and is able to carry out the processing of waste with liquid smoke independently, but the motivation for entrepreneurship from liquid smoke products has increased at the time of counseling, only 23.3 percent of participants were interested in entrepreneurship, but during a visit at liquid smoke factory even at the time of application all participants were interested in entrepreneurship because of the ease of process and high benefits.
\end{abstract}

Keyword: Liquid Smoke, Garbage, Kalibaru

\section{Pendahuluan}

Sampah merupakan bagian dari sesuatu yang sudah tidak dimanfaatkan, dibuang dan pada umumnya berasala dari kegiatan yang dilakukan manusia itu sendiri. Peningkatan aktivias manusia lebih lanjut menyebabkan bertambahnya jumlah sampah yang ada ( (Sulistyorini, 2005 ). Sampah itu sendiri dibagi atas dua yaitu sampah organik yaitu sampah yang berasal dari bagian hewan, tumbuhan dan manusia dan sampah anorganik yaitu sampah yang berasal dari bahan mineral seperti logam, kaca plastik.

Sampah organilk sendiri mengandung berbagai macam zat dan secara alami zat tersebut mudah terdekomposisi oleh pengaruh fisik, kimia, enzim yang dikandung oleh sampah itu sendiri (Wahyono, 2001). Pertumbuhan penduduk yang terus bertambah dari waktu ke waktu berdampak pada peningkatan timbunan sampah. Oleh karena itu pada suatu kawasan atau kota perlu suatu sarana pengelolaan sampah, salah satunya yaitu Tempat Pembuangan Sampah (TPA). Saat ini TPA yang berada di sebagian besar kota di Indonesia masih menerapkan sistem open dumping yaitu cara pembuangan sampah sederhana dimana sampah hanya dihamparkan pada suatu lokasi dan dibiarkan terbuka. Dalam undang-undang Nomor 18 Tahun 2008 tentang Pengelolaan Sampah juga dinyatakan bahwa penanganan sampah dengan pembuangan terbuka terhadap pemrosesan dilarang. Hal ini didasarkan pada akibat yang ditimbulkan yaitu gas-gas yang dihasilkan seperti $\mathrm{H} 2 \mathrm{~S}$ (gas Hidrogen Sulfida), metan dan Amoniak lepas ke udara. 
GANDRUNG: Jurnal Pengabdian Kepada Masyarakat ISSN: 2721-6136 (Online)

Hal ini terjadi juga pada TPA di Desa Kalibarumanis Kecamatan Kalibaru Kabupaten Banyuwangi, yang menerapkan sistem terbuka bau yang dihasilkan dari proses dekomposisi menyebar luas ke area masyarakat. Proses dekomposisi sampah organic oleh bakteri yang tidak terkendali umumnya berlangsung secara anaerobik (tanpa oksigen). Dari proses ini timbul gas-gas seperti $\mathrm{H}_{2} \mathrm{~S}$ yang memberi bau yang sangat menyengat sehingga proses ini disebut juga sebagai pembusukan.

Dari sinilah perlu adanya penanganan dikarenakan jumlah sampah organik sendiri lebih melimpah karena padatnya penduduk. Jika sampah organis lebih banyak maka, bau yang ditimbulkan akan lebih banyak pula. Hal ini mempengaruhi keadaan masyarakat sekitarnya. Sehingga diperlukan suatu solusi untuk menangani permasalahan tersebut yaitu dengan mendesinfeksi bakteri sampah tersebut dengan menggunakan Asap Cair, sehingga diharapkan akan menghilangkan bau sampah yang mengganggu lingkungan.

Asap cair merupakan senyawa-senyawa yang menguap secara simultan dari reaktor panas melalui teknik pirolisis (penguraian dengan panas) dan berkondensasi pada sistem pendingin (Simon, 2005). Proses pembuatan asap cair melalui beberapa tahapan yaitu pirolisis, kondensasi, dan redestilasi. Kayu atau serbuk kayu dipirolisis pada suhu tertentu hingga menghasilkan asap, kemudian asap yang dihasilkan dikondensasikan menjadi bentuk asap cair. Asap cair hasil kondensasi ini masih memiliki kandungan tar yang tinggi dan berwarna keruh sehingga perlu didestilasi berulang-ulang (Darmaji P. , 2002). Asap cair yang sudah mengalami redistilasi dapat langsung diaplikasikan dalam produk pangan seperti ikan dan belut (Utomo, 2009. ). Asap cair memiliki komponen utama yaitu asam, derivat fenol, dan karbonil yang berperan sebagai pemberi rasa, pembentuk warna, anti bakteri, dan antioksidan.

Secara umum proses pembuatan asap cair melalui tiga tahapan yaitu pirolisis, kondensasi, dan redistilasi ( (Darmaji P. , 2002); (Sari, 2007)). Pirolisis adalah proses pemecahan polimer menjadi molekul yang lebih kecil dengan menggunakan pembakaran. Suhu yang digunakan pada proses pirolisis ini tergantung dari jenis bahan baku kayu. Suhu untuk pirolisis dapat mencapai $450^{\circ} \mathrm{C}$, hal ini disebabkan kayu terdiri atas hemiselulosa, selulosa, dan lignin. Pirolisis hemiselulosa terjadi pada suhu 200-250 $\mathrm{C}$ dan menghasilkan senyawa furfural, furan, asam karboksilat, dan asam asetat. Pirolisis selulosa terjadi pada suhu $280-320^{\circ} \mathrm{C}$ dan menghasilkan senyawa asam asetat serta pirolisis lignin, pada suhu 400-450 $\mathrm{C}$ akan menghasilkan senyawa fenol dan eter fenolik (Girard, 1992). Proses kondensasi asap akan membentuk kondensat ekstrak kasar asap cair yang harus diredestilasi atau dimurnikan lagi untuk mendapatkan asap cair (Darmaji P. , 2002). Tahapan pembuatan asap cair dapat dilihat pada Gambar 2. Produksi asap cair dilakukan dengan memasukkan serbuk kayu/kayu/tempurung 
GANDRUNG: Jurnal Pengabdian Kepada Masyarakat ISSN: 2721-6136 (Online)

kelapa yang telah dikeringkan ke dalam pirolisator, ditutup dan dipanaskan pada suhu $200-450^{\circ} \mathrm{C}$. Pada kisaran suhu tersebut diharapkan tiga komponen yang berpengaruh pada komposisi fraksi asap cair yaitu hemiselulosa, selulosa, dan lignin telah mengalami pirolisis. Asap yang terbentuk dilewatkan dalam pipa kondensor dengan air sebagai media pendinginnya. Pemurnian asap cair dilakukan dengan cara redistilasi. Asap cair dimasukkan dalam labu destilasi dan dipanaskan pada suhu $100-200^{\circ} \mathrm{C}$, asap yang terbentuk kemudian dilewatkan dalam pipa kondensor dengan air sebagai media pendinginnya (Darmaji P. S., 1999). Balai Besar Riset Pengolahan Produk dan Bioteknologi telah mengembangkan desain alat pembuat asap cair skala laboratorium dan menguji coba dengan bahan baku tempurung kelapa. Tempurung kelapa sebanyak 500 gram dipirolisis selama 8 jam pada suhu $227,0-251,8^{\circ} \mathrm{C}$ dan menghasilkan rendemen asap cair sebanyak 48,10\% dengan produksi arang sebanyak 31,33\%, sedangkan pada suhu pirolisis $336,6-427,8^{\circ} \mathrm{C}$ diperoleh destilat sebesar $26,30 \%$ dengan produksi arang $26,30 \%$ (Sari, 2007).

Menurut (Maga, 1988), asap cair secara umum memiliki komposisi sebagai berikut : air 81-92\%; fenol 0,22-2,9\%; asam 2,8-4,5\%; karbonil 2,6-4,6\%; dan tar 1-17\%. Sedangkan menurut Bratzler et al. (1969) komponen utama kondensat asap kayu adalah karbonil 24,6\%; asam karboksilat 39,9\%; dan fenol 15,7\%. Komponen asap tersebut berfungsi sebagai antimikroba, antioksidan, pembentuk aroma, flavor, dan warna. Hasil penelitian (Tranggono., 1996), asap cair dari tempurung kelapa mempunyai 7 macam komponen yang dominan yaitu fenol, 3-metil-1.2- siklopentadion, 2-metoksifenol, 2-metoksi-4metilfenol, 4-etil-2-metoksifenol, 2.6-dimetoksifenol dan 2.5-dimetoksi benzil alkohol, yang kesemuanya larut dalam eter. Hasil penelitian (Sari, 2007) menyatakan bahwa komponen utama asap cair adalah 1,2-asam benzendikarboksilat dan dietil ester. Asap cair dari kayu jati, lamtorogung, mahoni, kamper, bangkirai, keruing dan batang kelapa menghasilkan asam (sebagai asam asetat) antara 4,27-11,30\%, senyawa fenolat (sebagai fenol) $2,10-5,13 \%$ dan senyawa karbonil (sebagai aseton) $8,56-15,23 \%$.

Zat-zat yang ada dalam asap merupakan bahan yang bersifat bakteriostatik dan bakteriosidal. Senyawa yang sangat berperan sebagai antimikrobial adalah senyawa fenol dan asam asetat. Asap cair akan menurunkan $\mathrm{pH}$ sehingga dapat memperlambat pertumbuhan mikroorganisme. Pada $\mathrm{pH}$ 4,0 asap cair mampu menghambat semua bakteri pembusuk dan patogen, sedangkan pada pH tinggi sekitar 6,0 penghambatan asap cair terhadap pertumbuhan bakteri mulai berkurang (Darmaji \& Izimoto, 1995). Pada pengenceran 10 kali, asap cair mampu menghambat pertumbuhan bakteri Pseudomonas fluorescence, Bacillus subtilis, Escherichia coli, dan Staphylococcus aureus (Darmaji P. , 1996).

Sehingga karena asap cair bersifat sebagai antibakteri maka asap cair dapat digunakan untuk menghilangkan bau sampah pada TPA di kalibaru, Banyuwangi. Bau tersebut terjadi dikarenakan 
GANDRUNG: Jurnal Pengabdian Kepada Masyarakat ISSN: 2721-6136 (Online)

banyaknya bakteri pada sampah yang mengubah bahan organik menjadi ammonia sehingga mengakibatkan bau yang cukup mengganggu lingkungan sekitar.

Skema penghilangan bau dengan cara melarutkam asap cair dalam air dengan perbandingan 3 $\%$ (tiga liter asap cair dilarutkan kedalam 100 Liter air), kemudian disemprotkan pada sampah.

\section{Metode}

Metode Pengabdian pengolahan sampah di desa kalibaru dilakukan dengan tiga tahapan, tahap pertama dilakukan adalah pembentukan dan diskusi serta penyuluhan pada kelompok masyarakat terkait pengolahan sampah yang terfokus pada penghilangan bau sampah dengan menggunakan larutan liquid smoke. Tahap ke dua dilakukan praktek pembuatan Liquid Smoke di Pabrik Asap Cair, UD Ketapang Raya 2, Bulusan Banyuwangi. Tahap Ketiga aplikasi Liquid smoke untuk menghilangkan bau sampah dengan membuat larutan liquid smoke 5\% (5 liter liquid smoke dilarutkan dalam 100 Liter Air), yang kemudian disemprotkan kepada sampah untuk penghilangan bau sampah di TPA kalibaru.

Pada setiap tahapan dilakukan evaluasi dengan metode angket dengan membagikan Kuesioner pada peserta yang dilakukan dengan cara memberi seperangkat pertanyaan tertulis kepada peserta pelatihan untuk dijawabnya. Dalam hal ini peneliti sudah membuat daftar pernyataan dengan kategori setuju dan tidak setuju. Teknik analisis data uji coba menggunakan teknik analisis data deskriptif persentase (\%) dengan rumus $P=\frac{n}{N} \times 100 \%$ (Hayudi, 2020)

$\mathrm{P} \quad=$ Persentase hasil

$\mathrm{n} \quad=$ Jumlah jawaban skor

$\mathrm{N} \quad=$ Jumlah jawaban maksimal

Adapun bagan Alir Pelaksanaan Pengabdian ditunjukkan pada Gambar 1. berikut: 


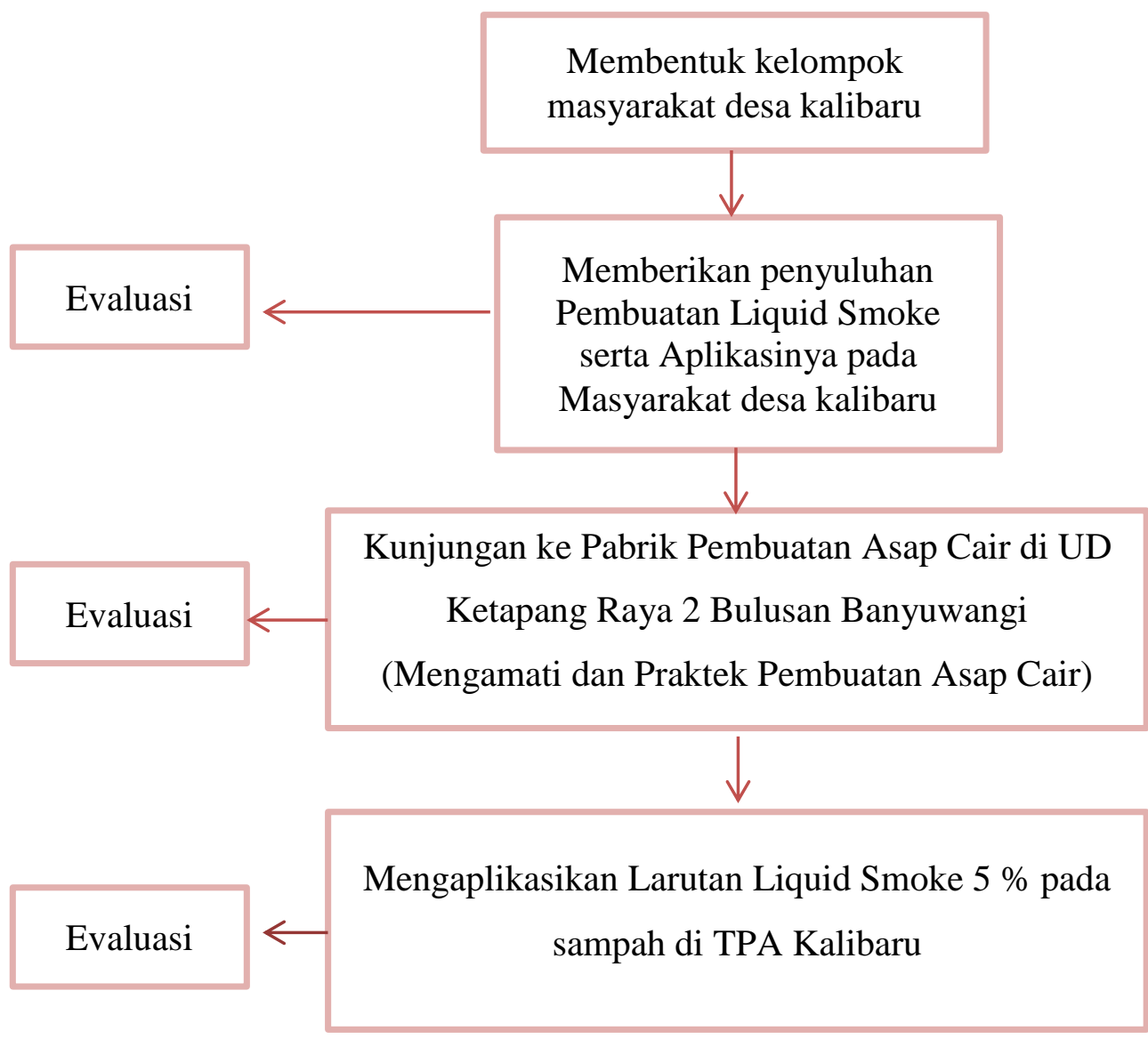

Gambar 1. Bagan Alir Pelaksanaan Pengabdian Masyarakat di Kecamatan kalibaru

\section{Hasil dan Diskusi}

Kegiatan pengabdian Masyarakat di kalibaru ini merupakan kegiatan TOT (Training of Trainer) yang diharapkan masyarakat yang dilatih bisa memberikan pelatihan kepada masyarakat yang lainnya, sehingga bisa diaksanakan secara berkelanjutan. Metode pengabdian dilakukan dengan tiga tahapan yaitu tahap pertama sosialisasi dengan masyarakat di kalibaru, tahap ke dua peninjauan pabrik asap cair oleh karang taruna kalibaru ke pabrik asap cair di Bulusan Kecamatan Kalipuro dan yang terakhir adalah pelaksanaan / aplikasi asap cair pada Tempat Pembuangan Akhir di kalibaru.

Pada setiap tahapan dibagikan angket untuk mengetahui pemahaman, kemanfaatan, dan aplikasi program tersebut di masyarakat. Hasil dari angket pada saat penyuluhan disajikan pada tabel v. 1 berikut:

Tabel 1 Angket pada penyuluhan pembuatan dan Aplikasi Liquid Smoke di Kalibaru

\begin{tabular}{llll}
\hline No. & Item & Jumlah & $\%$ \\
\hline 1. & Kegiatan ini bermanfaat & 30 & 100 \\
\hline 2. & $\begin{array}{c}\text { Manfaat yang diperoleh : } \\
\text { a) Menambah wawasan pada pelatihan }\end{array}$ & 30 & 100 \\
\hline
\end{tabular}




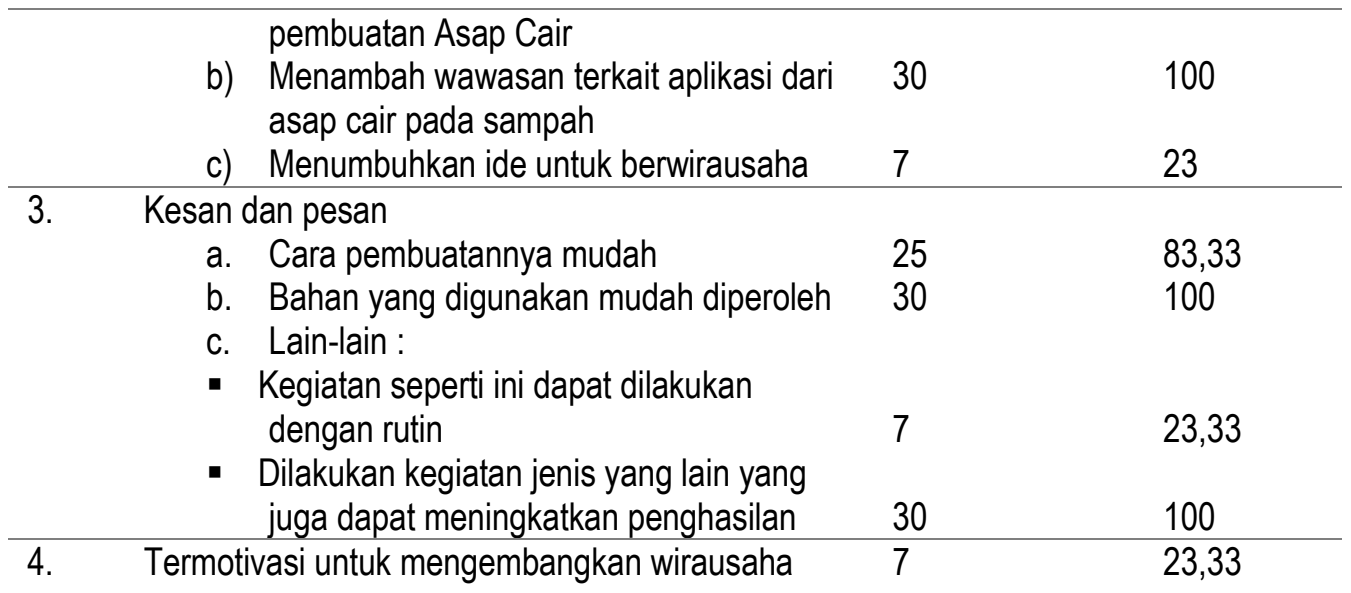

Dari hasil penyuluhan yang dilakukan keseluruhan peserta pelatihan menyatakan kegiatan ini bermanfaat dan tertarik hal ini dikarenakan dari proses pengaplikasian yang cukup mudah serta pemanfaatanya yang luas, sehingga masyarakat kalibaru sangat antusias untuk melaksanakannya. Namun terkait motivasi berwirausaha masih sangat sedikit yang ingin melakukan karena mereka hanya fokus untuk mengatasi problema bau pada sampah bukan untuk kegiatan yang lainnya seperti penjualan.

Kesan masyarakat terhadap hasil penyuluhan ini bervariasi, hampir keseluruhan peserta beranggapan pengaplikasian tempurung kelapa cukup mudah, dan bahan yang digunakan mudah diperoleh karena banyuwangi merupakan penghasil kelapa terbesar di Jawa Timur, dan mengharapkan ada kegiatan lain yang serupa untuk pemberdayaan masyarakat. Namun untuk pengaplikasian asap cair terhadap sampah cuma 23 persen masyarakat yang ingin rutin dilakukan karena proses ini dirasa cukup mudah sehingga mereka mampu melaksanakan kegiatan ini sendiri dengan pengendalian sampah dari masing masing rumah sebelum dibawa ke TPA.

Pada tahap dua proses kunjungan ke pabrik Liquid Smoke, dari 30 peserta yang mengikuti kunjungan hanya 20 peserta karena sebagian izin bekerja, 20 peserta melihat proses pembakaran tempurung kelapa menjadi arang dan liquid smoke seperti yang ditunjukkan pada gambar di bawah ini

Para peserta melihat seluruh rangkaian proses pembuatan liquid smoke, setelah melihat dbagikan angket untuk mereview apa yang telah dikerjakan, hasil dari angket tersebut disajikan pada Gambar 2 berikut. 
GANDRUNG: Jurnal Pengabdian Kepada Masyarakat

ISSN: 2721-6136 (Online)

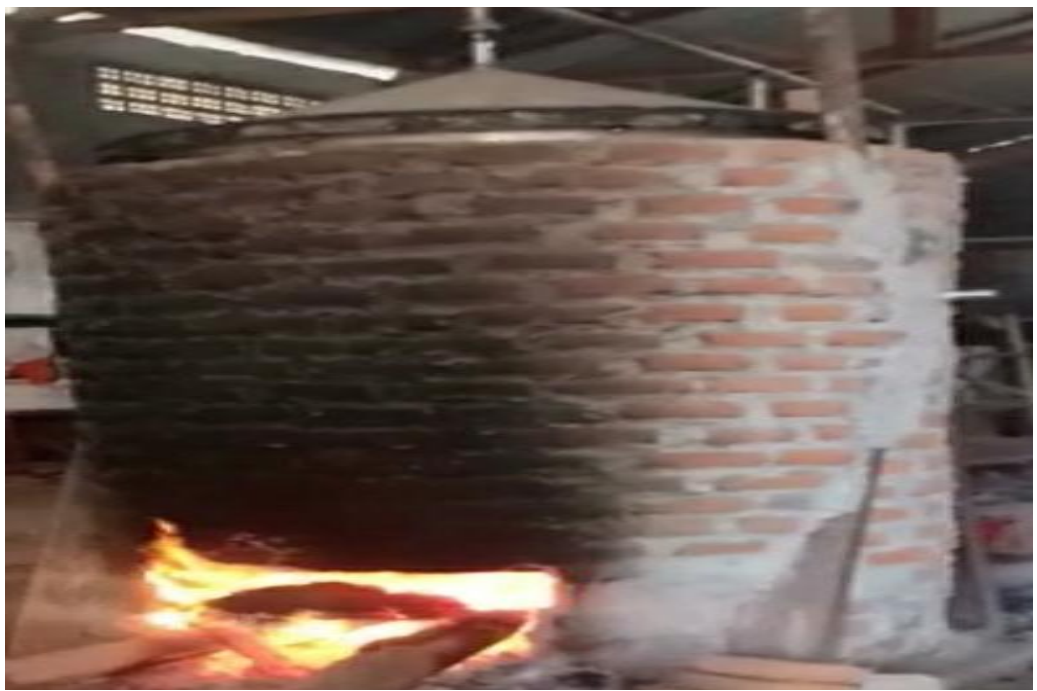

Gambar 2 Proses pembakaran tempurung kelapa menjadi Liquid Smoke

Tabel 2 Angket pada kunjungan di Pabrik pembuatan Liquid Smoke di Bulusan

\begin{tabular}{|c|c|c|c|}
\hline No. & Item & Jumlah & $\%$ \\
\hline 1. & Kegiatan ini mudah dipahami & 20 & 100 \\
\hline \multirow[t]{4}{*}{2.} & \multicolumn{3}{|l|}{ Manfaat yang diperoleh : } \\
\hline & $\begin{array}{l}\text { a) Menambah wawasan pada pelatihan } \\
\text { pembuatan Asap Cair }\end{array}$ & 20 & 100 \\
\hline & $\begin{array}{l}\text { b) Menambah wawasan tentang pengolahan } \\
\text { limbah kelapa }\end{array}$ & 20 & 100 \\
\hline & c) Menumbuhkan ide untuk berwirausaha & 20 & 100 \\
\hline \multirow[t]{5}{*}{3.} & \multicolumn{3}{|l|}{ Kesan dan pesan } \\
\hline & a. Cara pembuatannya mudah & 10 & 50 \\
\hline & b. Menghasilkan produk yang bermanfaat & 20 & 100 \\
\hline & c. Pengalaman anda bertambah & 20 & 100 \\
\hline & $\begin{array}{l}\text { d. Mencoba membuat dan mengaplikasikan } \\
\text { pada warqa sekitar }\end{array}$ & 20 & 100 \\
\hline
\end{tabular}

Dari hasil kunjungan ke Pabrik asap cair di Bulusan secara keseluruhan peserta sangat antusias dan secara umum tertarik dan berencana untuk menjadikan ini sebagai suatu usaha, hal ini berbanding terbalik pada saat penyuluhan dimana pada saat itu masyarakat hanya mengetahui hanya teori saja sehingga gambaran terkait usaha yang dilakukan belum terbayang, namun setelah melihat proses pembuatan secara keseluruhan mereka berencana untuk melakukan usaha dibidang itu, namun mereka masih kesulitan terkait prosesnya karena membutuhkan alat yang relative mahal, oleh karena itu sebagian peserta $(50 \%)$ menganggap pembuatannya susah Sedangkan pada saat pengaplikasian di kalibaru keseluruhan peserta hadir yang ditunjukkan pada gambar 3 dan cukup antusias hal ini diketahui dari hasil angket pada tabel 3 berikut. 


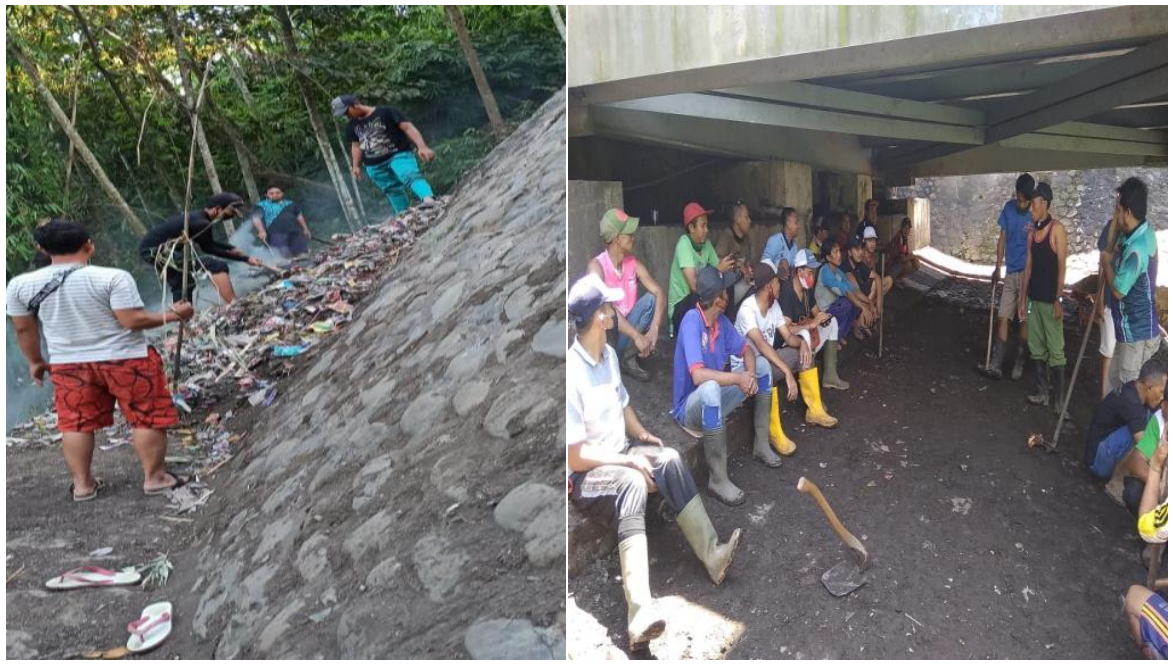

Gambar 3. proses pengaplikasian Liquid Smoke pada penghilangan bau sampah

Tabel 3 Pengaplikasian Liquid Smoke pada sampah di TPA Kalibaru

\begin{tabular}{llll}
\hline No. & Item & Jumlah & $\%$ \\
\hline 1. & Kegiatan ini mudah dipahami & 30 & 100 \\
\hline 2. & $\begin{array}{l}\text { Aplikasi Liquid Smoke untuk menghilangkan } \\
\text { bau pada TPA kalibaru ini cukup mudah untuk } \\
\text { dilakukan }\end{array}$ & 30 & 100 \\
\hline 3. & $\begin{array}{l}\text { kegiatan ini menambah wawasan tentang } \\
\text { manfaat dari Liquid Smoke }\end{array}$ & 30 & 100 \\
\hline 4 & $\begin{array}{l}\text { hasil pelatihan ini dapat menurunkan atau } \\
\text { menghilangkan bau pada sampah }\end{array}$ & 30 & 100 \\
\hline 5 & $\begin{array}{l}\text { pengalaman akan bertambah setelah } \\
\text { mengikuti pelatihan ini }\end{array}$ & 30 & 100 \\
\hline 6 & $\begin{array}{l}\text { Dapat melatih dan mengaplikasikan hasil } \\
\text { pelatihan ini pada warga dusun di sekitar }\end{array}$ & 30 & 100 \\
\hline 7 & $\begin{array}{l}\text { Termotivasi untuk mengembangkan wirausaha } \\
\text { dalam bidang ini }\end{array}$ & 30 & 100 \\
\hline
\end{tabular}

Data dari angket di atas dapat disimpulkan keseluruhan peserta dapat memahami, melakukan dan mengaplikasikan proses penghilangan bau sampah dengan liquid smoke, selain itu para peserta ingin merintis usaha baru terkait pembuatan Liquid Smoke.

\section{Kesimpulan}

Kesimpulan didapatkan pada kegiatan pengabdian kepada masyarakat tentang aplikasi Liquid Smoke di TPA kalibaru antara lain: Masyarakat mampu melakukan pengelolaan sampah dengan menghilangkan bau menggunakan Liquid Smoke, masyarakat mampu mentraining warga lainnya dalam pengelolaan sampah, Masyarakat optimis untuk mengembangkan usaha pembuatan liquid smoke untuk 
GANDRUNG: Jurnal Pengabdian Kepada Masyarakat ISSN: 2721-6136 (Online)

dikomersialkan

\section{Daftar Referensi}

Bratzler, L. S. (1969). . Smoke flavour as related to phenol, carbonil and acid content of bologna. J. Food Sci., 34: 146.

Darmaji, P. (1996). Aktivitas antibakteri asap cair yang diproduksi dari bermacam-macam limbah pertanian. . Agritech. 16 (4): , 19-22.

Darmaji, P. (2002). Optimasi proses pembuatan tepung asap. . Agritech. 22 (4), : 172-177.

Darmaji, P. a. ( 1995.). Antibacterial effects of spices on fermented meat. The Scientific Reports of The Faculty of Agriculture Okayama University., 83(1): 9-15.

Darmaji, P. S. (1999). Produksi asap rempah cair dan limbah padat rempah dengan cara pirolisa. . Agritech. 19 (1): , 11-15.

Girard, J. (1992). Smoking in Technology of Meat Products. . Clemont Ferrand. Ellis Horwood. New York. , pp.123-129.

Hayudi. (2020). Inovasi Pembelajaran (Inklusi) Pendidikan Jasmani Berbasis Permainan Kecil Untuk Mahasiswa Berkebutuhan Khusus. , Jurnal Kejaora ISSN: 2541-5042, Volume 5 Nomor 2.

Maga, J. (1988). Smoke in Food Processing. CRC Press inc. Florida., pp.1-3: 113-138.

Sari, R. U. (2007). Uji coba alat penghasil asap cair skala laboratorium dengan bahan pengasap serbuk gergaji kayu jati sabrang atau sungkai (Peronema canescens). Jurnal Pascapanen dan Bioteknologi 2(1):; 27-34.

Simon, R. C. (2005). Composition and analysis of liquid smoke flavouring primary products. J. Food Sci. , 28: 871-882.

Sulistyorini, L. (2005 ). Pengelolaan Sampah dengan Cara Menjadikannya Kompos. Jurnal Kesehatan Lingkungan. , 77-84.

Tranggono. (1996). Identifikasi asap cair dari berbagai jenis kayu dan tempurung kelapa. . Seminar Nasional Pangan dan Gizi \& Kongres PAPTI. (p. 22). Yogyakarta.: PAPTI.

Utomo, B. F. ( 2009. ). Pengaruh konsentrasi larutan asap cair terhadap mutu belut asap yang dihasilkan. . Jurnal Pascapanen dan Bioteknologi 4 (1): , 49-58.

Wahyono, S. (2001). Pengolahan Sampah Organik dan Aspek Sanitasi. Jurnal Teknologi Lingkungan, h:113-118. 